\title{
Cara Mudah Menghafal Al Qur'an Melalui Metode Tarjim Di Pondok Pesantren Tahfidzul Qur'an Safinatul Huda Iii Bandung Diwek Jombang
}

\author{
Sunardi \\ Sekolah Tinggi Ilmu Tarbiyah al Urwatul Wutsqo - Jombang \\ Email: sunardi.ppuw@gmail.com \\ Kamaliyatul Izzah Muqoddasah \\ Universtas Pesantren Tinggi Darul Ulum - Jombang \\ Email: Kamaliya41@gmail.com
}

\begin{abstract}
Everyone has their own method or method of memorizing. But the most widely used are those that are suitable and enjoyable for each individual. When examined, most methods suitable for each person are obtained through several attempts. The method or method of memorizing effective Al-Qur'an applies diversity not uniformity. That is, between one person and another, the same method applies, depending on the character, absorption and memory of each. This method proved to be accurate for someone not necessarily accurate for others. The purpose of this study is to investigate the implementation of the tarjim method, the supporting and inhibiting factors in memorizing the Qur'an. The application of the tarjim method is a foreign grammar study that emphasizes grammar analysis, vocabulary memorization, discourse translators, and writing exercises. This method emphasizes reading, writing and translation skills.
\end{abstract}

Keywords: Memorizing Al-Qur'an, Tarjim Method

\begin{abstract}
Abstrak: Setiap orang memiliki cara atau metode sendiri dalam menghafal. Namun yang paling banyak digunakan adalah yang cocok dan menyenangkan bagi tiap individu. Jika diteliti, kebanyakan metode yang cocok bagi setiap orang diperoleh melalui beberapa kali percobaan. Hal atau cara metode menghafal AlQur'an yang efektif berlaku keberagaman bukan keseragaman. Maksudnya, antara satu dan lain orang berlaku metode yang tidak sama, tergantung pada karakter, daya serap dan daya ingat masing-masing. Metode ini terbukti jitu bagi seseorang belum tentu jitu pula bagi orang lain. Tujuan penelitian ini untuk mengetuahi bentuk implementasi metode tarjim, faktor pendukung dan penghambat dalam menghafal Al-Qur'an. Penerapan metode tarjim merupakan kajian tata bahasa asing yang menekankan analisa tata bahasa, penghafalan kosa kata, penerjemah wacana, dan latihan menulis. Metode ini mementingkan kecakapan membaca, menulis, dan terjemah.
\end{abstract}

Kata Kunci: Menghafal Al-Qur'an, Metode Tarjim 
Al-Qur'anul karim adalah mukjizat Islam yang kekal dan mukjizatnya selalu diperkuat oleh kemajuan ilmu pengetahuan. Ia diturunkan Allah SWT kepada Rasulullah, Muhammad SAW untuk mengeluarkan manusia dari suasana yang gelap menuju yang terang, serta membimbing mereka kejalan yang lurus. (Manna Khalil al-Qattan, 2014:1). Melalui penghafal AlQur'an Allah menjaga keutuhan kitab suci-Nya. Tingginya kesadaran umat Islam untuk menghafal AlQur'an semakin mengokohkan AlQur'an sebagai kitab suci yang paling banyak dihafal. Kaum muslimin menghafalkan ayat demi ayat, surah demi surah dan juz demi juz kemudian menyimpannya di dada mereka. Sehingga mustahil bagi mereka yang anti islam untuk mengubah atau memalsukan AlQur'an.

Penghafal Al-Qur'an adalah manusia pilihan Allah SWT, mereka sangat istimewa di sisi Allah, Allah meninggikan kedudukan mereka baik didunia maupun diakhirat. Mereka menjaga kalamullah maka mereka pun dijaga oleh Allah SWT. Mereka memuliakan Al-Qur'an maka Allah pun akan memuliakan mereka. Ada berjuta keistimewaan yang dimiliki oleh kafilah Qur'an. Rasulullah SAW pernah bersabda :

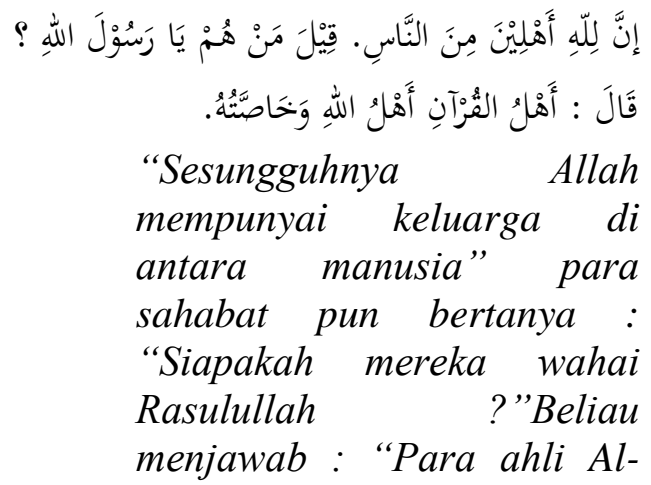

Qur'an, mereka lah keluarga Allah dan pilihan-pilihanNya. "(Imam Abdul Rouf An-Nawawi, Jami'u Shogir, th.:72)

$$
\text { خَيْرُكْمْ مَنْ تَعَلَّمَ الْقُرَآنَ وَعلََّمَهُ }
$$

"Sebaik-baik orang di antara kalian adalah orang yang mempelajari (al-Qur'an dan mengajarkannya." HR. Bukhari) (Imam Abdul Rouf An-Nawawi, th.12)

Hadits ini mengisyaratkan bahwa kebaikan seseorang bisa dilihat dari kesungguhannya dalam belajar dan mengajarkan Al-Qur'an. Seolah-olah kemuliaan seseorang bisa dilihat dari keakrabannya dengan Al-Qur'an, baik dalam mempelajari, mengajarkan, membaca, menghafal, mentadaburi, dan mengamalkannya. Al-Qur'an menjadi takaran baik buruknya manusia dihadapan Allah Swt. (Saied Al-Makhtum, 2016: 23-26). Sebagian besar umat Islam beranggapan bahwa menghafal AlQur'an itu susah. Diantara penyebabnya pertama, mereka belum meyakini ayat Allah yang menegaskan kemudahan Al-Qur'an. Kedua, belum pernah serius menghafalkannya. Biasanya yang mengatakan bahwa menghafal itu susah, mereka belum pernah menghafal atau pernah menghafal tapi tidak serius, alias hanya cobacoba. Lantas ketika mendapat sedikit kesulitan, mereka langsung berhenti menghafal, lalu mengatakan bahwa menghafal itu susah.

Nikmatnya menghafal itu justru di saat ada sedikit kesulitan, karena itulah kesempatan anda 
untuk lebih banyak membaca, mengulang dan mendalami maknanya. Orang yang merasakan nikmatnya menghafal biasanya ingin menikmati hafalannya lebih lama. Ibarat makan, ia tidak terburuburu untuk mengakhiri hidangannya.

Al-Qur'an adalah kitab suci yang paling mudah dipelajari dan dihafal. Salah satu buktinya adalah Al-Qur'an merupakan satu-satunya kitab yang paling banyak dihafal oleh manusia di dunia. Ini selaras dengan firman Allah dalam AlQur'an :

"Dan Sesungguhnya Telah kami mudahkan Al-Quran untuk pelajaran, Maka Adakah orang yang mengambil pelajaran?" (QS. Al-Qomar : 17) (Departemen Agama RI, 2010: 529-530).

Setiap orang memiliki cara atau metode sendiri dalam menghafal. Namun demikian, yang paling banyak digunakan adalah yang cocok dan menyenangkan bagi tiap individu. Jika diteliti, kebanyakan metode yang cocok bagi setiap orang diperoleh melalui beberapa kali percobaan. (Amjad Qosim, 2013:101)

Hal atau cara metode menghafal Al-Qur'an yang efektif berlaku keberagaman, bukan keseragaman. Maksudnya, antara satu dan lain orang berlaku metode yang tidak sama, tergantung pada karakter, daya serap dan daya ingat masing-masing. Metode ini terbukti jitu bagi seseorang belum tentu jitu pula bagi orang lain. Berkaitan dengan ini, ada orang-orang yang dapat menemukan sendiri metode yang tepat bagi mereka. Tetapi tak sedikit pula orang yang bingung dan perlu menimba pengalaman orang lain serta bimbingan guru untuk sampai pada metode yang tepat bagi dirinya.

Menghafal Al-Qur'an adalah proyek kita meninggalkan dunia, dengan derajat yang istimewa, dan tempat yang dijanjikan adalah surga. Oleh karenanya, jujurlah kepada Allah, maka Allah akan jujur kepada anda. Jadikanlah Al-Qur'an sebagai prioritas dalam hidup anda, maka anda akan mampu menghafalnya. Anda juga akan mengamalkannya, dan Al-Qur'an pun akan menggiring anda untuk masuk ke dalam surga yang penuh dengan sungai-sungai. (Majdi Ubaid Al-Hafizh, 2014:2930).

"Di tempat yang disenangi di sisi Tuhan yang berkuasa." $(Q S$. Al-Qomar : 55)(Departemen Agama RI, 2010:53)

Kita diperintahkan oleh Allah untuk menetapi Al-Qur'an dan mengamalkannya sepanjang siang dan malamsecara total. Selain itu juga, merenungkan ayat-ayat dan menghayati maknanya.

Katakanlah: "Sesungguhnya Aku hendak memperingatkan kepadamu suatu hal saja, yaitu supaya kamu menghadap Allah (dengan ikhlas) berdua- dua atau sendiri-sendiri; Kemudian kamu fikirkan (tentang Muhammad) tidak ada penyakit gila sedikitpun pada kawanmu itu. dia tidak lain hanyalah pemberi peringatan bagi kamu sebelum (menghadapi) azab yang keras" (Saba':46) 
Berapa banyak orang yang membaca Al-Qur'an, mempelajari serta menghafalnya, tetapi cahaya iman belum merasuk kedalam hatinya sehingga tidak semakin meningkat keimanannya secara langsung. Terhadap orang seperti ini, maka Al-Qur'an akan menjadi penentang yang mencelakakannya, bukan pembelanya.

Pondok Pesantren Tahfidzul

Qur'an Safinatul Huda Bandung Diwek selalu mengikuti perkembangan zaman, di pondok ini menggunakan beberapa metode untuk meningkatkan kemampuan menghafal Al-Qur'an bagi para santri. Salah satu metode yang digunakan di pondok ini untuk membantu santri dalam menghafal Al-Qur'an ialah dengan metode tarjim. Metode tarjim adalah metode yang menekankan pada pengapalan kosa kata (mufrodat) dan penerjemahan ayat-ayat Al-Qur'an. Tidak bisa dipungkiri bahwa orang yang memahami makna dan kandungan ayat-ayat yang akan dihafal akan lebih mudah untuk menghafalkannya. Jika kita rutin setiap hari menjaga dan menambah hafalan, daya ingat akan terpelihara. Selain itu bagi yang menerapkan metode menghafal dengan mengetahui artinya terlebih dahulu, maka hal ini akan mendapatkan pemahaman yang lebih baik tentang isi Al-Qur'an. Membaca dan menghafalkan Al-Qur'an juga akan memberikan ketenangan hati dan dapat memberikan pertolongan atau syafa'at di hari kiamat.

Berbicara tentang menghafal Al-Qur'an, santri dipondok pesantren Tahfidzul Qur'an Safinatul Huda III seluruhnya adalah penghafal AlQur'an. Pada tahap awal dan belum resmi menjadi pesantren hanya berjumlah 9 santri, tetapi sekarang sudah mencapai lebih dari 250 santri, karena keterkaitannya dengan metode yang diterapkan dipondok tersebut.

Setelah peneliti melakukan observasi di Pondok Pesantren Tahfidzul Qur'an Safinatul Huda III Bandung Diwek Jombang, peneliti mendapatkan informasi bahwasanya penerapan metode tarjim di bagi menjadi dua kelompok, yakni hari jum'at, sabtu, dan ahad untuk kelompok pertama dan hari senin, selasa dan rabu untuk kelompok kedua. Adapun untuk hari kamis mereka isi dengan kegiatan rutinan Pondok tiap kamis malam Jum'at.

Pondok pesantren Tahfidzul Qur'an Safinatul Huda didirikan oleh Kiai Ghozi Rofi'udin, S.HI. Berdirinya ini adalah atas dasar ingin mencetak generasi muda hamilil Qur'an, hafidhul Qur'an, lafdhan wa ma'nan wa 'amalan.Santri di pondok Pesantren ini rata-rata menyelesaikan hafalan dalam jangka cepat. Adapun santri yang kemampuan menghafalnya tinggi mampu menyelesaikan hafalan hanya dalam waktu singkat. Ini suatu upaya pengasuh untuk mewujudkan masyarakat yang paham Al-Qur'an dan menjadi manusia yang cerdas dan berbudi luhur.

Penelitian ini, difokuskan pada menghafal Al-Qur'an di Pondok Pesantren Tahfidzul Qur'an Safinatul Huda III. Berdasarkan penelitian diataslah maka peneliti mengambil judul : "Implementasi Metode Tarjim dalam Menghafal AlQur'an di Pondok Pesantren 
Tahfidzul Qur'an Safinatul Huda III Bandung Diwek Jombang”.

\section{Fokus Penelitian}

1. Implementasi metode tarjim di Pondok Pesantren Tahfidzul Qur'an Safinatul Huda III Bandung Diwek Jombang.

2. Faktor pendukung dan penghambat dalam menghafal Al-Qur'an melalui metode tarjim di Pondok Pesantren Tahfidzul Qur'an Safinatul Huda III Bandung Diwek Jombang.

\section{Metode Penelitian}

Penelitian tentang Cara

Menghafal Al Qur'an Melalui Metode Tarjim di Pondok Pesantren Tahfidzul Qur'an Safinatul Huda III Bandung Diwek Jombang ini menggunakan jenis penelitian lapangan (field research) menggunakan paradigma penomenologi dan pendekatan penelitian kualitatif. Sumber penelitian ini meliputi orang yaitu kyai, para ustadz dan ustadzah,para senior, dan santri. Sumber data yeng berupa tempat adalah sarana, dan prasarana kerja dan aktivitas di Pondok Pesantren Tahfidzul Qur'an Safinatul Huda. Sedangakan data sekunder berupa dokumen, yaitu beberapa arsip pondok yang berkaitan dengan profil Pondok Pesantren Tahfidzul Qur'an Safinatul Huda, dokumen, buku-buku, catatancatatan, buku absen, buku rapat dan lain sebagainya yang berkaitan dengan penelitian ini.

Teknis pengupulan data dalam penelitian ini menggunakan Interview (wawancara), observasi dan dokumentasi. Sedangkan teknis analisis data penelitian ini menggunakan redukasi data, penyajian data dan verifikasi data.

\section{Pembahasan}

1. Implementasi Metode Tarjim dalam Menghafal Al-Qur'an di Pondok Pesantren Tahfidzul Qur'an Safinatul Huda III Bandung Diwek Jombang

a. Implementasi

1) Metode Tarjim Menghafal Al-Qur'an adalah bentuk taqarrub kepada Allah yang paling agung. Nabi Muhammad SAW bersabda :

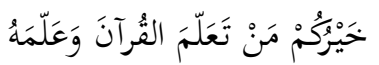

"Sebaik-baik kalian adalah orang yang belajar AlQur'an dan mengajarkannya." (HR. Bukhari) (Imam Abdul Rouf An-Nawawi, 12)

Menghafal Al-Qur'an itu, terdapat metode khusus yang dipakai oleh calon tahfidz. Penerapan metode tarjim merupakan kajian tata bahasa asing yang menekankan analisa tata bahasa, penghafalan kosa kata, penerjemah wacana, dan latihan menulis. Metode ini mementingkan kecakapan membaca, menulis, dan terjemah. Bisa disebut klasifikasi dari segi isim, fi'il atau huruf. Kemudian, jika ada kosa kata yang lupa, maka diperbolehkan membuka kamus lafdzul Qur'an 
dengan tujuan untuk mengingat kembali kosa kata atau terjemah yang sudah dihafal. Sebagaimana yang diceritakan Kiai Ghozi Rofi'udin kepada peneliti bahwa:

Metode tarjim adalah mempelajari Al-Qur'an melalui kemampuan berbahasa Arab (pendekatan kosa kata). Penerapan metode tarjim bermodel kelompok. Satu ustadz/ah membawai maksimal 20 santri dan kemudian pelatihan diadakan satu hari cukup satu jam untuk memahami metode tarjim tersebut. Metode tarjim mempunyai buku atau media belajar dalam memahami Al-Qur'an secara lafdhiyah atau perkata (kamus Lafdzul Qur'an dan program Pelatihan Terjemah AlQur'an). Dalam buku tersebut lafazh yang tercetak merah adalah kata baru, karena di dalam Al-Qur'an banyak kata yang diulangulang, maka semakin banyak yang dipelajari semakin sedikit lafadz yang tercetak merah, itu berarti semakin mudah untuk kita memahaminya. Kamus tersebut dibagi secara per juz, karena setiap juz mempunyai klasifikasi lafadz yang berbeda. Seperti juz 1 lafdhiyah atau perkata, terjemah bahasa Indonesia dan klasifikasi lafadznya dari segi isim, fi'il atau huruf. (Kiai Ghozi Rofi'udin, 27 April 2017, jam 13.00 WIB)

Hal senada diungkap oleh ustadzah Nur Ummatul Khiftia kepada peneliti bahwa:

Metode tarjim itu metode terjemahan yang dipakai untuk memahami AlQur'an, dengan begitu kita bisa dapat mengetahui isi Al-Qur'an. Disini menggunakan metode tarjim perkata, ada buku tersendiri untuk pembelajaran metode tarjim. Dalam penerapan metode tarjim ini dibagi menjadi dua kelompok, setiap kelompok terdiri dari 20 orang. Tak bisa dipungkiri bahwa santri yang menerapkan metode tarjim dalam menghafal AlQur'an melalui pemahaman makna ayat-ayat yang akan dihafal lebih mudah untuk masuk ke otak. Khususnya ketika menghafal surat-surat yang mengandung kisah atau ayat-ayat yang mempunyai sababun nuzul (sebab turun) yang sudah sangat popular. Begitu juga dengan ayat-ayat yang berkaitan dengan hukumhukum fiqh, seperti berwudhu, kafarat sumpah, kafarat zihar, puasa, diyat pembunuhan bersalah, atau hukum-hukum lainnya. (Nur Ummatul Khiftia, 14 April 2017, jam 13.00 WIB)

Penerapan metode tarjim di Pondok Pesantren Safinatul Huda III Bandung Diwek 
Jombang sebagai berikut pertama Satu kelas maksimal 20 santri yang dibawai oleh satu ustadz. Kedua, Menyiapkan Mushaf beserta kamus Lafdzul Qur'an sebelum memulai menerapkan metode tarjim. Ketiga, Membaca dengan tartil 1 kaca atau satu halaman yg akan diterjemahkan.

Ketiga,Membaca satu ayat kemudian diterjemahkan perpotong. Keempat, Setelah menerjemahkan perpotong, dilanjutkan menerjemah secara langsung dalam satu ayat. Kelima, Jika ada arti yang lupa diperbolehkan untuk membuka kamus Lafdzul Qur'an. Keenam, Setelah selesai penerjemahan satu halaman, maka diulang kembali dari awal dengan mengartikan per ayat. Ketujuh, Untuk mengetahui seberapa keberhasilan santri dalam menghafal melalui metode tarjim, maka akan diadakan evaluasi pada tiap pergantian juz. (Nur Ummatul Khiftia, 4 April 2017, jam 13.00 WIB)

2) Hukuman

Hukuman yang diberikan oleh pengurus kepada santri yang melanggar peraturan yaitu Pertama, Digundul apabila ketahuan merokok atau berpacaran. Kedua, Dihukum berdiri sambil mengaji apabila ketahuan pergi ke warnet. Ketiga, Ro'an apabila tidak mengikuti kegiatan malam di pondok. Keempat, Apabila telah melanggar peraturan lebih dari $3 \mathrm{x}$ maka akan dikeluarkan dari pondok, begitu juga apabila ada kasus disekolahnya.

3) Bentuk kegiatan

Kegiatan para santri setiap hari dan bulanan yang dilaksanakan di Pondok adalah, Khutbah dan Adzan, Hataman yang dilaksanakan setiap Kamis Legi di masjid Safinatul Huda III, Hataman di luar Pondok ketika ada undangan, Muhadhoroh, Puisi dan Pantun, MQQ dan MHQ, MFQ (CCQ), Banjari (Diba'an)

4) Jadwal kegiatan

Selain menghafal AlQur'an, di Pondok Pesantren Safinatul Huda III Bandung Diwek Jombang juga ada kegiatan pengajian kitab dan Qiro'ah, berikut jadwal pengajian kitab dan qiro'ah. Jadwal Pengajian Kitab di Pondok Pesantren Tahfidzul Qur'an Safinatul Huda III

Pengaplikasian metode tarjim dalam menghafal al-Qur'an di Pondok Pesantren tahfidzul Qur'an safinatul huda III Bandung Diwek Jombang

Mengaplikasikan metode tarjim, perlu melihat konsep dasar metode ini sebagaimana dijelaskan agar tidak keluar dari karakteristiknya, karena Al-Qur'an mudah dihafal dan mudah hilang dari ingatan. Hafalan yang sudah disetorkan ke instruktur dan tersimpan di 
memori otak belum terjamin akan terjaga terus melekat selama-lamanya. Hafalan dapat bertahan paling lama 12 jam. Upaya ustadz/ustadzah dalam mendidik santrinya menghafal Al-Qur'an adalah dengan memberikan motivasi dan dukungan penuh terhadap santri melalui pengkajian dan pengarahan atas keistimewaan pahala orang yang menghafal Al-Qur'an. Selain memberikan motivasi kepada santri, ustadz/ustadzah juga selalu memberikan pengkajian ilmu tajwid, sehingga santri tidak hanya lancar menghafal AlQur'an saja akan tetapi lancar makhraj dan tajwidnya dengan benar dan baik. Hal ini didukung dengan pernyataan bapak Kiai Ghozi Rofi'udin yang menyatakan bahwa:

Ustadz/ustadzah adalah orang yang pertama menjadi dasar penentu keberhasilan santrinya, berhasil tidaknya hafalan santri tergantung pengembangan pengajaran ustadz/ustadzah. Selain memberikan motivasi kepada santri, ustadz/ustadzah juga harus memberikan pengkajian ilmu tajwid, sehingga santri tidak hanya lancar menghafal Al-Qur'an. Pada prinsipnya, orang menghafal Al-Qur'an itu tidak boleh lupa atau melupakan hafalannya. Kalau itu terjadi, sia-sialah pekerjaan yang telah dia lakukan. Seharusnya apa yang sudah dihafal dengan metode-metode yang baik tidak lepas dan hilang dari ingatan. Hanya saja, begitulah kenyataan yang sering terjadi banyak orang yang dulunya hafal Al-Qur'an dengan lancar, kini tidak lagi, atau banyak dari hafalannya yang hilang karena tidak rajin melakukan takrir. (Kiai Ghozi Rofi'udin, 27 April 2017, jam 13.00 WIB)

Ungkapan sama juga dari Adin Rajabi, dia mengatakan bahwa: Saya itu bisa menghafalkan AlQur'an karena dapat motivasi dari guru saya, saat itu saya masih kelas 3 MI. beliau berkata bahwa, kalau kita ingin menjadi keluarga Allah kita harus hafalan Al-Qur'an. Kita harus berkaca kepada orang yang lebih dari pada kita, dan kita harus bisa seperti dia. Agar hafalan kita bisa lebih terjaga, kita harus lebih sering nderesnya dari pada malasnya. Disini diadakan muroqobah 1 juz tiap harinya agar hafalan santri itu lebih terjaga dan lebih melekat dalam ingatan santri. (Kiai Ghozi Rofi'udin, 27 April 2017, jam 13.00 WIB) Berdasarkan hasil wawancara dengan Ustadzah Nur Ummatul Khiftia selaku ketua Pondok Putri pada tanggal 14 april 2017, pengaplikasian metode tarjim di Pondok Pesantren Tahfidzul Qur'an Safinatul Huda III melalui takrir (mengulang hafalan), antara lain : Pertama, Takrir sendiri ialah Seorang yang menghafal Al-Qur'an harus bisa memanfaatkan waktu untuk takrir dan menambah hafalan. Hafalan yang baru harus selalu di takrir, minimal dua kali sehari dalam jangka 
waktu satu minggu. Sedang hafalan yang lama harus di takrir setiaphari atau dua hari sekali. Artinya semakin banyak hafalan harus semakin banyak pula waktu yang dipergunakan untuk takrir. Kedua, Takrir dalam sholat ialah Seorang yang menghafal Al-Qur'an hendaknya bisa memanfaatkan hafalannya sebagai bacaan dalam shalat, baik sebagai imam maupun dalam shalat sendiri. Selain menambah keutamaan (pahala), cara demikian juga akan menambah kemantapan hafalan. Ketiga, Takrir bersama ialah Seorang yang menghafal Al-Qur'an perlu melakukan takrir bersama dengan dua teman atau lebih. Dalam takrir ini setiap orang yang membaca materi takrir yang ditetapkan secara bergantian, misalnya masing-masing satu halaman, dua halaman atau ayat per ayat. Ketka seorang membaca, yang lain mendengarkan dan membetulkan jika ada yang salah. Keempat,Takrir kepada Instruktur atau Guru ialah Seorang yang menghafal AlQur'an harus selalu menghadap instruktur atau guru untuk takrir hafalan yang sudah diajukan. Materi takrir yang dibaca harus lebih banyak dari pada materi tahfidz, yaitu satu banding sepuluh. Artinya, apabila penghafal sanggup menyetorkan hafalan baru dua halaman setiap hari, maka harus diimbangi dengan takrir 20 halaman (satu juz).
Dalam proses menghafal AlQur'an, keinginan cepat khatam 30 juz memang sangatlah wajar. Namun jangan sampai keinginan tersebut membuat anda terburu-buru dalam menghafalkan AlQur'an dan pindah kehafalan yang baru. Sebab bila demikian, dikhawatirkan akan melalaikan hafalan yang sudah pernah dihafal tidak diulang kembali karena lebih fokus pada hafalan baru dan tidak mentakriri hafalan yang lama. Hal ini didukung dengan pernyataan Kiai Ghozi Rofi'udin yang menyatakan bahwa:

Jika menginginkan kualitas hafalan yang baik dan kuat, maka sebaiknya jangan terburu-buru ketika menghafalkannya. Oleh karena itu, jangan tergesa-gesa berpindah ke ayat yang lain hingga ayat yang sebelumnya benar-benar hafal dan kuat. Selain itu juga, tidak hanya fokus ke perpindahan surat yang sebelumnya, tetapi harus fokus ke surat yang terdahulu yang sudah pernah dihafalkan. (Kiai Ghozi Rofi'udin, 27 April 2017, jam 13.00 WIB)

2. Faktor pendukung dan penghambat menghafal al-Qur'an melalui metode tarjim

Menghafal Al-Qur'an, tidak lepas dari faktor pendukung dan penghambat yang berkenaan dengan metode tarjim di Pondok Pesantren Tahfidzul Qur'an Safinatul Huda III Bandung Diwek Jombang. Diantara faktor yang mendukung dalam menghafal Al-Qur'an di Pondok 
Pesantren ini adalah karena adanya kerjasama dari pengasuh, pengurus dan ustadz dalam memotivasi, membimbing dan memberi suri tauladan kepada santri dan dalam membimbing santri untuk menghafal Al-Qur'an.

a. Faktor pendukung dalam menghafal al-Qur'an melalui metode tarjim

Berdasarkan hasil wawancara dengan Pengasuh Pondok, Ustadz dan para santri pada tanggal 15 April 2017, faktor pendukung dalam menghafal Al-Qur'an antara lain : Pertama, Memperbaiki bacaan sebelum menghafal ialah Sebelum memulai menghafal Al-Qur'an, pastika bacaan sudah benar terlebih dahulu. Dianjurkan untuk mulai mencoba belajar Ilmu Tajwid. Disimak oleh Syaikh AlHafidz terlebih dahulu sebelum mulai menghafal. Sebab, seseorang yang menghafal dengan bacaan yang salah, nantinya akan sulit untuk memperbaiki bacaannya. Hal ini bukan berarti menganjurkan untuk menunda menghafal sampai selesai belajar tajwid, tapi justru menganjurkan untuk segera menghafal dengan tetap mencari kesempatan untuk memperbaiki bacaan. Misalnya dengan mendengarkan kasetkaset bacaan Syaikh AlMinsyawi atau Al-Hasri sebelum mulai menghafal halaman tertentu bagi yang belum belajar Ilmu Tajwid. Hal ini didukung oleh pernyataan Kiai Ghozi Rofi'uddin yang menyatakan bahwa:
Seperti kita ketahui, Al-Qur'an itu diturunkan ditanah Arab dengan bahasa Arab pula. Kita yang bahasa sehari-harinya bukan Arab, tentu harus banyak belajar dalam hal pengucapan Arab. Dalam menghafal Al-Qur'an, kita harus menguasai ilmu tajwid. Allah SWT memerintahkan kepada seluruh umat Islam agar membaca Al-Qur'an dengan benar sesuai dengan yang telah ditetapkan dalam ilmu tajwid. Karena itu, menguasai ilmu tajwid terlebih dahulu sebelum membaca AlQur'an, apalagi menghafalkannya adalah perkara wajib. (Kiai Ghozi Rofi'udin, 27 April 2017, jam $13.00 \mathrm{WIB})$.

Hal senada diungkap oleh Ihya'ul Ulum kepada peneliti bahwa:

Membaca Al-Qur'an memang dibutuhkan keterampilan dan kemampuan dalam hal pengucapan. Sebab bila pengucapannya salah, maka hal itu dapat mengurangi, bahkan menghapus dari pahala membaca Al-Qur'an. Sebagaimana kita ketahui, membaca satu huruf saja mendapat pahala sepuluh kali lipat, bagaimana jika membaca satu ayat, satu surat, satu juz, atau bahkan khatam. Jadi menguasai ilmu tajwid itu sangat penting sebelum kita membaca atau menghafalkan Al-Qur'an. (Kiai Ghozi Rofi'udin, 27 April 2017, jam 13.00 WIB) 
Kedua, Menggunakan mushaf Al-Qur'an dari satu cetakan ialah Sebagaimana kita ketahui bersama, bahwa Al-Qur'an telah dicetak dalam berbagai corak serta gaya tulisan yang beragam, baik dari segi bentuk maupun ukurannya. Selain itu, ada Al-Qur'an yang satu halamannya berisi dua belas baris, empat belas baris, lima belas baris, serta beberapa corak dan bentuk Al-Qur'an lainnya. Ketiga, Mampu menyambung dari awal sampai akhir sebelum berpindah ke surat lain. Menyambung hafalan antara ayat satu dengan lainnya lebih diutamakan dari pada menghafal ayat-ayat baru. Pastikan dapat menyambung setiap ayat dengan ayat berikutnya, dan jangan mulai menghafal ayat baru kecuali jika hafalan sudah benar-benar kuat dalam menyambungkan ayat-ayat sebelumnya. Keempat, Menentukan target hafalan setiap hari. Seorang santri harus menentukan target hafalan setiap harinya, sebab pikiran bawah sadar serta kemampuan otak lebih memahami hal-hal yang terperinci dan tidak menyukai hal-hal yang bersifat umum.

Sebagaimana yang diceritakan oleh Kiai Ghozi Rofi'uddin kepada peneliti bahwa:

Sebaiknya tidak tidur malam kecuali setelah menyelesaikan target hafalan, baik 7 halaman atau 7 baris. Point terpenting adalah menentukan rincian target hafalan setiap harinya dan jangan mengubah jadwal

harian sampai
menghafalkannya bisa
sempurna. (Kiai $\quad$ Ghozi
Rofi'udin, 27
13.00 Wril 2017, jam

Kelima, Melazimi Halaqah Tahfizh ialah Sering kita dapati seseorang yang sangat bersemangat melakukan sesuatu, dan kemudian ia benar-benar berusaha dan mewujudkan keinginannya tersebut dengan tekad untuk meraih hasil yang sempurna. Namun, tak lama kemudian seiring waktu berlalu, ambisinya melemah. Semangatnya memudar dan kerjanya mulai lamban. Akhirnya, ia justru berhenti total sebelum semua rencananya bisa terwujud. Itulah tipu daya dan gangguan setan terkutuk. Setan selalu berusaha keras secara perlahan merasuk kedalam jiwa seseorang mukmin agar menjauhkannya dari segala jenis kebaikan. Dalam kondisi seperti ini, cara yang paling tepat memerangi setan adalah harus bergabung dengan kawan, saudara dan kenalan. Tujuannya adalah agar saling tolong-menolong dalam menghafal Al-Qur'an. Allah berfirman :

Artinya :"Tolong-menolonglah kamu dalam (mengerjakan) kebajikan dan takwa, dan jangan tolong-menolong dalam berbuat dosa dan pelanggaran. dan bertakwalah kamu kepada Allah, Sesungguhnya Allah amat berat siksa-Nya." (QS. Al- 
Maidah : 2) (Departemen Agama RI, 2010: 15)

Sebagaimana yang diceritakan oleh Kiai Ghozi Rofi'uddin kepada peneliti bahwa:

Rasulullah SAW bersabda : "Setan bersama orang yang sendirian. Dan ia akan menjauh dari dua orang". Jika anda menemukan dalam diri anda semangat yang tinggi dan membara untuk menghafal AlQur'an, disamping waktu yang luang dan cukup bergabunglah dalam sebuah kelompok bersama beberapa kawan atau saudara yang mendukung tujuan anda. (Kiai Ghozi Rofi'udin, 27 April 2017, jam 13.00 WIB).

Keenam, Menguatkan dalam shalat ialah Memanfaatkan shalat dengan mengulang dan memantapkan hafalan.

Hal ini juga dsampaiakan oleh Kiai Ghozi Rofi'uddin yang menyatakan bahwa:

Kalian boleh membaca atau mengulang hafalan sesuai dengan kemampuan kalian. Bila hanya mampu 1 atau 2 halaman per shalat, maka lakukanlah. Yang penting bukanlah terletak pada jumlah halaman yang bisa dibacadalam shalat, tetapi istiqamah. Intinya harus istiqomah dalam mengulang hafalan, berapa pun jumlah ayat yang bisa diulang. Dengan istiqomah, insyaAllah hafalan akan tetap melekat dalam ingatan. (Kiai Ghozi Rofi'udin, 27 April 2017, jam 13.00 WIB).
Ketujuh, Memahami Maknanya ialah Memahami isi atau kandungan ayat akan member kemudahan tersendiri dalam menghafal Al-Qur'an. Orang yang paham bahasa AlQur'an (Arab) biasanya lebih cepat hafal karena ia mengerti makna alur cerita ayat yang dihafal. Ia tidak sekedar mengandalkan kecerdasan otak, tapi juga pemahaman. Bagi yang tidak paham bahasa Arab, bisa menggunakan mushaf terjemahan biasa atau perkata yang sekarang sudah beredar dengan berbagai bentuk. Dengan memahami makna ayat yang dihafal, mengahafal itu akan terasa lebih mudah, cepat, dan menyenangkan. Kiai Ghozi Rofi'uddin yang menyatakan bahwa:

Tak bisa dipungkiri bahwa orang yang memahami makna dan kandungan ayat-ayat yang akan dihafal akan lebih mudah untuk menghafalnya. Khususnya, ketika menghafal surat-surat yang mengandung kisah atau ayat-ayat yang mempunyai sababun nuzul (sebab turun) yang sudah sangat popular. Di pondok ini, diadakan pelatihan terjemah Al-Qur'an bagi para santri. Ini bertujuan untuk memudahkan santri dalam menghafal AlQur'an. Jadi selain mereka hafal Arabnya, mereka juga bisa tahu artinya. (Kiai Ghozi Rofi'udin, 27 April 2017, jam 13.00 WIB) 
Hal senada diungkap oleh $\mathrm{M}$. Ridho'i kepada peneliti bahwa: Al-Qur'an itu sungguh luar biasa. Semakin dipahami maknanya makan kita akan semakin penasaran untuk mendalaminya. Susunan kalimatnya yang indah serta maknanya yang dalam membuat ayat-ayat Al-Qur'an begitu mempesona. Menghafal dengan pamahaman akan lebih membekas di hati dan lebih melekat di otak. Di pondok ini, ada pelatihan untuk penerjemahan Al-Qur'an yang biasa dikatak dengan Metode Tarjim Al-Qur'an. Metode ini sangan membantu kami, kami akan lebih mudah untuk mengahafal ayat-ayat AlQur'an karena kami sudah mengetahui terlebih dulu maknanya.( M. Ridho'i, 1 Mei 2017, jam 13.00 WIB).

Berdasarkan hasil wawancara dengan Pengurus Pondok pada tanggal 1 Mei 2017, faktor pendukung dalam menghafal Al-Qur'an antara lain : Pertama, Selalu mengikuti kegiatan-kegiatan yang berhubungan dengan AlQur'an. Kedua, Lingkungan banyak para penghafal. Ketiga, Mengikuti deresan Al-Qur'an diluar pondok atau diluar jam kegiatan.

Keempamt, Mengikuti perlombaan musabaqoh yang berada di Pondok agar bisa semakin aktif dalam mengulang-ulang hafalan Al-Qur'an. Kelima, Kembali kepada Himmah dan kemauan inisiatif pada anak itu sendiri. b. Faktor penghambat dalam menghafal al-Qur'an melalui metode tarjim

Berdasarkan hasil wawancara dengan Pengasuh Pondok, Ustadz dan para santri pada tanggal 15 April 2017, faktor penghambat dalam menghafal Al-Qur'an antara lain :

1) Kurang Perhatian

Secara sederhana dapat dikatakan bahwa konsentrasi tidak dapat terwujud tanpa adanya perhatian. Jika melakukan sesuatu yang penting tanpa ada unsur yang dapat membuat tertarik, maka harus memunculkan faktor yang menguatkan perhatian secara acak. Ini untuk melahirkan motivasi pada riri seseorang. Jika tidak, maka otak akan menetang dan enggan untuk berkonsentrasi.

2) Suka Menunda

Sebagian orang melakukan penundaan terhadap hal-hal yang tidak menarik bagi mereka, tanpa berpikir mengenai akibat yang ditimbulkan dari penundaan ini. Penundaan ini adalah ungkapan dari salah satu bentuk "rela dengan kegagalan kecil"

Waktu adalah umur kehidupan manusia di dunia. Ia adalah modal perdagangan manusia dengan Allah SWT. Karena itu, hindarilah sikap mengulur-ulur waktu dan menyibukkan diri dengan hal-hal yang memalingkan 
diri dari Al-Qur'an. Jangan biasakan mengatakan, "Besok saya akan menghafal". "Besok saya akan membaca", dan seterusnya. Sebab, menghafal kitabullah tidak dapat terlaksana dengan menyia-nyiakan waktu dan menuruti hawa nafsu.

Hal ini didukung oleh pernyataan Kiai Ghozi Rofi'uddin yang menyatakan bahwa:

Dalam menghafal juga perlu mengetahui sebab-sebab yang dapat menghambat atau faktor penghambat dalam menghafal AlQur'an. Adakalanya orang kurang menaruh perhatian terhadap hafalan. Akibatnya, tidak terbesit kesan yang kuat dalam pikirannya tentang menghafal. Dengan diadakannya Tarjim AlQur'an, diharapkan santri bisa lebih semangat dalam menghafal Al-Qur'an. Tapi perlu kita ketahui juga, kita harus memperhatikan keadaan lingkungan disekitarnya. Kalau temannya tidak rajin, anak akan mudah terbawa suasana. Seorang penghafal itu harus mempunyai target hafalan untuk mereka sendiri, mereka menarget hatam 2 atau sampai 3 tahun berarti mereka tidak boleh untuk menyia-nyiakan waktu. Maka dari itu, pengasuh, pengurus dan para ustadz/ah terus mengontrol anak-anak agar belajar disiplin dalam berbagai hal.(Kiai Ghozi Rofi'udin, 27 April 2017, jam 13.00 WIB).

3) Gangguan Lingkungan Di antara berbagai penghalang tersebut adalah : hawa nafsu yang selalu condong untuk bersenangsenang dan benci terhadap sifat mujahadah (bersungguh-sungguh), setan yang selalu menghalangi untuk menghafal Al-Qur'an.

Hal ini didukung oleh pernyataan Ihya'ul Ulum yang menyatakan bahwa:

Anak-anak itu menganggap muroja'ah lebih memberatkan dari pada awal menghafal. Padahal tiap harinya diadakan mudarrosah dan muroqobah 1 juz untuk mengulang hafalan agar lebih terjaga. Selain itu ada pelatihan tarjim Al-Qur'an untuk memudahkan mereka dalam menghafal, karena dengan ini mereka akan mengetahui makna dari ayat yang dihafal. Anak-anak masih kurang mempunyai tekad dan niat yang lurus dalam menghafal Al-Qur'an. Kalau libur pondok dan tidak digunakan untuk kegiatan Al-Qur'an mereka akan merasa senang karena bisa bersenang-senang untuk sejenak. (Ihya'ul Ulum, 15April 2017, jam $13.00 \mathrm{WIB})$. 
4) Kurangnya Muroja'ah

Para ulama tafsir menjelaskan, manusia dinamakan insane yaitu berasal dari kata insanan yang artinya lupa. Sebab, manusia mempunyai sifat lupa. Karena itu, jika para penghafal Al-Qur'an lupa sebagian hafalannya, ia tidak perlu terlalu gelisah. Karena hal itu wajar bagi manusia. Lupanya Nabi SAW adalah menunjukkan bahwa beliau adalah manusia biasa. Tapi beliau adalah ma'shum dan imam bagi seluruh hafizh AlQur'an.

Sebagaimana penjelasan Ari Seno kepada peneliti bahwa: Al-Qur'an itu mudah dihafal, tapi kalau tidak dimuroja'ah akan cepat hilang dari ingatan kita. Maka dari itu hilangkan rasa malas dalam diri kita, perbaiki niat kita dari sekarang. Tetaplah mengulang hafalan secara terus-menerus dan jagalah apa yang telah dihafal dengan terus mengulang hafalan, mendengarkan dan meminta saudara kita untuk mendengarkan hafalan kita. Untuk lebih memudahkan kita dalam mengingat hafalan, kita bisa membacanya disaat sholat. Semoga Allah SWT menjadikan kita sebagai manusia ahli Al-Qur'an dan manusia yang paling dekat di sisi-Nya. (Ari Seno, 21 April 2017, jam 13.00
WIB).

\section{Analisis}

1. Implementasi Metode Tarjim

Metode Tarjim merupakan kajian tata bahasa asing yang menekankan analisa tata bahasa, penghafalan kosa kata, penerjemah wacana, dan latihan menulis. Metode ini mementingkan kecakapan membaca, menulis, dan terjemah. Bisa disebut klasifikasi dari segi isim, fi' $i l$ atau huruf.

Penerapan Metode Tarjim di Pondok Pesantren Tahfidzul Qur'an Safinatul Huda III yaitu suatu model pembelajaran dengan cara membentuk kelompok. Satu kelompok ini maksimal 20 orang yang di ajar oleh satu Ustadz/ah.

Penerapan Metode tarjim ini mempunyai buku atau media belajar dalam memahami AlQur'an secara lafdhiyah atau perkata (kamus Lafdzul Qur'an dan program Pelatihan Terjemah Al-Qur'an). Dalam buku tersebut lafazh yang tercetak merah adalah kata baru, karena di dalam AlQur'an banyak kata yang diulangulang, maka semakin banyak yang dipelajari semakin sedikit lafadz yang tercetak merah, itu berarti semakin mudah untuk kita memahaminya. Kamus tersebut dibagi secara per juz, karena setiap juz mempunyai klasifikasi lafadz yang berbeda. Seperti juz 1 lafdhiyah atau perkata, terjemah bahasa Indonesia dan klasifikasi lafadznya dari segi isim, fi'il atau huruf. 
Penerapan metode tarjim di Pondok Pesantren Tahfidzul Qur'an Safinatul Huda III Bandung Diwek Jombang sebagai berikut : Pertama, Satu kelas maksimal 20 santri yang dibawai oleh satu ustadz /ah. Kedua, Menyiapkan Mushaf beserta kamus Lafdzul Qur'an sebelum memulai menerapkan metode tarjim. Ketiga, Membaca dengan tartil 1 kaca atau satu halaman yg akan diterjemahkan. Keempat, Membaca satu ayat kemudian diterjemahkan perpotong. Kelima, Setelah menerjemahkan perpotong, dilanjutkan menerjemah secara langsung dalam satu ayat. Keenam, Jika ada arti yang lupa diperbolehkan untuk membuka kamus Lafdzul Qur'an. Ketujuh, Setelah selesai penerjemahan satu halaman, maka diulang kembali dari awal dengan mengartikan per ayat. Kedelapan, Untuk mengetahui seberapa keberhasilan santri dalam menghafal melalui metode tarjim, maka akan diadakan evaluasi pada tiap pergantian juz.

Sedangkan Pengaplikasian Metode Tarjim dalam menghafal Al-Qur'an di Pondok Pesantren Tahfidzul Qur'an Safinatul Huda III Bandung Diwek Jombang melalui takrir (mengulang hafalan), antara lain :

a. Takrir sendiri

Santri yang menghafal AlQur'an di Pondok Pesantren Tahfidzul Qur'an Safinatul Huda III memanfaatkan waktu untuk takrir dan menambah hafalan. Hafalan yang baru di takrir santri minimal dua kali sehari dalam jangka waktu satu minggu. Sedang hafalan yang lama di takrir ssantri setiap hari atau dua hari sekali. Artinya semakin banyak hafalan santri maka semakin banyak pula waktu yang dipergunakan untuk takrir.

b. Takrir dalam sholat Santri yang menghafal AlQur'an di Pondok Pesantren Tahfidzul Qur'an Safinatul Huda III bisa memanfaatkan hafalannya sebagai bacaan dalam shalat, baik sebagai imam maupun dalam shalat sendiri. Selain menambah keutamaan (pahala), cara demikian juga akan menambah kemantapan hafalan santri.

c. Takrir bersama

Santri yang menghafal AlQur'an di Pondok Pesantren Tahfidzul Qur'an Safinatul Huda III melakukan takrir bersama dengan dua teman atau lebih. Dalam takrir ini setiap orang yang membaca materi takrir yang ditetapkan secara bergantian, misalnya masing-masing satu halaman, dua halaman atau ayat per ayat. Ketika seorang santri membaca, yang lain mendengarkan dan membetulkan jika ada yang salah.

d. Takrir kepada instruktur atau guru

Santri yang menghafal AlQur'an di Pondok Pesantren Tahfidzul Qur'an Safinatul Huda III harus selalu menghadap instruktur atau guru untuk takrir hafalan yang sudah diajukan. Materi takrir yang dibaca harus lebih banyak 
dari pada materi tahfidz, yaitu satu banding sepuluh. Artinya, apabila santri sanggup menyetorkan hafalan baru dua halaman setiap hari, maka harus diimbangi dengan takrir 20 halaman (satu juz).

Pelaksanaan kegiatan metode tarjim yang optimal akan terjadi jika ada interaksi positif antara pengasuh, ustadz/ah dan santri. Pengasuh sebagai teladan dan juga fasilitator yang harus dapat memfasilitasi santri dalam mengembangkan diri dengan harapan proses dan hasil menghafal Al-Qur'an di Pondok Pesantren Tahfidzul Qur'an Safinatul Huda III dapat memberikan pengalaman dan kesan yang baik dan mampu membentuk kepribadian santri secara hamilil Qur'an hafidhul Qur'an lafdhan wa ma'nan wa 'amalan.

Ustadz/ustadzah adalah orang yang pertama menjadi dasar penentu keberhasilan santrinya, berhasil tidaknya hafalan santri tergantung pengembangan pengajaran ustadz/ustadzah. Selain memberikan motivasi kepada santri, ustadz/ustadzah juga harus memberikan pengkajian ilmu tajwid, sehingga santri tidak hanya lancar menghafal Al-Qur'an.

Yahya Abdul Fattah Az Zawawi mengatakan kepada calon penghafal Al-Qur'an bahwa Selama Anda dapat menemukan guru mengaji yang ahli atau Qori' yang bagus bacaannya, maka hal itu akan sangat bagus. Guru tersebut dapat mendengarkan bacaan Anda dan membenarkan kesalahan Anda serta mengajari Anda tentang ilmu tajwid. Hal ini sangat bermanfaat bagi diri Anda, sehingga Anda bisa bersama para malaikat Safaratul Kiramil Bararah (Yahya Abdul Fattah Az-Zawawi, 2013)

Sesuai dengan teori bahwa penerapan Metode Tarjim itu tidak lepas dari peran Pengasuh dan Ustadz/ah. Pengasuh sebagai teladan dan juga fasilitator yang harus dapat memfasilitasi santri dalam mengembangkan diri dan Ustadz/ustadzah adalah orang yang pertama menjadi dasar penentu keberhasilan santrinya.

2. Faktor pendukung dan penghambat metode tarjim

Setiap jalan menuju kebaikan mesti dipenuhi duri yang menghalangi pejalan kaki untuk sampai pada tujuan. Menghafal Al-Qur'an merupakan aktifitas yang sungguh sangat mulia, baik dihadapan Allah maupun dalam pandangan manusia. Sedemikian banyak waktu yang tercurah, konsentrasi pikiran yang terpusat, bahkan tenaga dan biaya juga ikut terkuras. Semua diniatkan untuk menggapai ridlo Allah, tanpa ada hasrat sedikitpun menjadikannya sebagai sumber penghasilan ataupun sanjungan. Dibalik kilau cahaya kemuliaan tersebut, tersembur pula serabut-serabut duri godaan yang senantiasa menghadang sewaktu-waktu. Jadi, siapapun yang pernah menjalani 
proses menghafal Al-Qur'an bisa dipastikan pernah merasakan pahitnya cobaan dan manisnya godaan. Tentu, jenis cobaan dan godaan tiap-tiap orang berbeda. Adapun kemampuan menghalau godaan itu sangat tergantung pada tingkat ketulusan niat dan kedalaman iman yang terpatri dihati.

Menghafal Al-Qur'an merupakan ibadah yang sangat mulia. Kegiatan tersebut termasuk kesibukan yang terpuji. Lebihlebih jika kegiatan tersebut dibarengi dengan niat mendekatkan diri kepada Allah SWT dan sekaligus merenungi ayat-ayat-Nya, kegiatan ini akan menjadi ketaatan yang berpahala besar. Persiapan yang matang dengan menjaga etika sebelum dan ketika menghafal Al-Qur'an diharapkan akan memberikan hasil yang sempurna.

Menghafal Al-Qur'an di Pondok Pesantren Safinatul Huda III, tidak lepas dari faktor pendukung dan penghambat yang berkenaan dengan proses menghafal AlQur'an. Diantara faktor yang mendukung antara lain : Memperbaiki bacaan sebelum menghafal, Menggunakan satu mushaf Al-Qur'an, Menentukan target hafalan setiap hari, Melazimi halaqah tahfizh, Membantu menguatkan dalam shalat.

Menurut Wiwi Alawiyah Wahid, hal yang dipersiapkan sebelum menghafal Al-Qur'an yaitu Niat yang ikhlas, meminta izin kepada orang tua atau suami, mempunyai tekad yang besar dan kuat, istiqomah, harus berguru kepada yang ahli, mempunyai akhlak terpuji, berdoa agar sukses menghafal Al-Qur'an, memaksimalkan usia, dianjurkan menggunakan satu jenis AlQur'an, dan lancar membaca AlQur'an. (Wiwi Alawiyah Wahid, 2012).

Hal senada diungkap oleh Kiai Ghozi Rofi'udin bahwa sebuah sarana yang tidak akan pernah siasia ialah berdo'a kepada Allah SWT dengan tulus ikhlas. Memohon kepada Allah SWT agar Dia menganugerahkan nikmat hafal Al-Qur'an pada diri santri. Selain itu menjadikan niat santri ikhlas karena Allah SWT semata, serta memberikan kemudahan bagi santri dalam beramal.

Adapun sebab-sebab yang membantu dalam menghafal AlQur'an antara lain mencintai AlQur'an, mendengarkan bacaan kaset-kaset Al-Qur'an, membantu menguatkan hafalan dalam shalat, menghilangkan penyakit hati (sombong, iri, dengki dll), tidak menunda-nunda waktu untuk memulai menghafal, memperhatikan ayat-ayat yang memiliki kesamaan lafadz, menguasai ilmu tajwid, memahami makna sebelum menghafal dan sering mengulangulang bacaan.

Begitu juga sebaliknya, setiap kegiatan yang kita lakukan pasti terdapat faktor yang menghambatnya. Dalam usaha pasti ada hambatan, baik yang datangnya dari diri sendiri maupun dari luar. Faktor penghambat atau kendala dalam menghafal Al-Qur'an di Pondok 
Pesantren Tahfidzul Qur'an Safinatul Huda III terbagi menjadi dua yakni faktor internal dan faktor eksternal, yang dimaksud faktor internal adalah faktor yang timbul dari dalam individu penghafal Al-Qur'an seperti Kurang Perhatian, Suka Menunda, kenakalan santri yang melanggar tata tertib pondok. Yang dimaksud faktor eksternal adalah faktor yang timbul dari lingkungan, masyarakat dan keluarga.

Yahya Abdul Fattah Az Zawawi mengatakan kepada calon penghafal Al-Qur'an bahwa Selama Anda dapat menemukan orang yang baik untuk dijadikan teman dalam menghafal AlQur'an bersama Anda, maka hal itu akan sangat membantu. Usahakan mencari teman yang yang setara atau lebih baik dari kemampuan Anda. Hal ini akan sangat bermanfaat bagi diri Anda, diantaranya Anda memiliki teman yang senasib sepenanggungan. Teman yang ikhlash karena Allah, mencintai Anda, dan Anda pun mencintainya karena Allah. Ia akan bersama Anda karena Allah dan berpisah dengan Anda juga karena Allah. Ia juga menjadi penolong dan penyemangat bagi diri Anda, sebaliknya, Anda juga menjadi penolong dan penyemangat baginya untuk menghafal Al-Qur'an dan tetap konsisten. Anda dapat mendengarkan hafalannya dan ia pun jugadapat mendengarkan hafalan Anda, sehingga Anda berdua dapat saling membenarkan apabila ada kesalahan.(Yahya Abdul Fattah Az-Zawawi, 2013).
Menurut Mukhlisoh Zawawie bahwa Hambatan-hambatan yang dihadapi oleh calon seorang hafidz yaitu: sibuk dan tidak memiliki banyak waktu, hati tidak jernih dan kurang fokus karena problematika hidup, bosan dan malas ketika memulai hafalan atau ditengah hafalan, faktor usia, tidak percaya diri karena hafal AlQur'an adalah anugerah Allah, lemah ingatan, dan takut lupa dan berdosa.(Mukhlisoh Zawawie, 2011).

Hal senada diungkap oleh Kiai Ghozi Rofi'udin bahwa dalam menghafal juga perlu mengetahui sebab-sebab yang dapat menghambat atau faktor penghambat dalam menghafal AlQur'an. Adakalanya santri kurang menaruh perhatian terhadap hafalan. Akibatnya, tidak terbesit kesan yang kuat dalam pikirannya tentang menghafal. Tapi perlu kita ketahui juga, kita harus memperhatikan keadaan lingkungan disekitarnya, masih ada santri yang terbawa dengan lingkungannya. Kalau lingkungannya baik, memungkinkan santri akan lebih semangat dalam menghafal. Tapi kalau lingkungannya kurang kondusif, yang ada santri hanya akan bermalas-malasan dan hanya suka bercanda dengan temantemannya. Karena itulah pintarpintarnya santri untuk meluruskan. (Kiai Ghozi Rofi'udin, 27 April 2017, jam 13.00 WIB).

\section{Kesimpulan}

Berdasarkan dari semua
pemaparan dan pembahasan 
sebelumnya, maka dapat ditarik kesimpulan beberapa hal penting dan dominan yang disesuaikan dengan fokus penelitian yaitu sebagai berikut:

1. Implementasi Metode Tarjim dalam menghafal Al-Qur'an di Pondok Pesantren Tahfidzul Qur'an Safinatul Huda III yaitu suatu model pembelajaran dengan cara membentuk kelompok. Satu kelompok ini maksimal 20 orang yang di ajar oleh satu Ustad atau ustadzah. Sedangkan Pengaplikasian Metode Tarjim dalam menghafal Al-Qur'an di Pondok Pesantren Tahfidzul Qur'an Safinatul Huda III Bandung Diwek Jombang melalui takrir (mengulang hafalan), antara lain Pertama, Takrir sendiri, Kedua, Takrir dalam sholat. Ketiga, Takrir bersama. Keempat, Takrir kepada Instruktur atau Guru.

2. Faktor Pendukung dan Penghambat Menghafal AlQur'an Melalui Metode Tarjim

a. Faktor Pendukung menghafal Al-Qur'an melalui metode tarjim antara lain Pertama, Memperbaiki bacaan sebelum menghafal.

Menggunakan satu mushaf Al-Qur'an. Kedua, Menentukan target hafalan setiap hari. Ketiga, Melazimi halaqah tahfizh. Keempat, Membantu menguatkan dalam shalat

b. Faktor Penghambat menghafal Al-Qur'an melalui metode tarjim terbagi menjadi dua antara lain : Pertama, Faktor Internal yang dimaksud adalah faktor yang timbul dari dalam individu penghafal Al-Qur'an seperti kurang perhatian, suka menunda, kenakalan santri yang melanggar tata tertib pondok. Kedua, Faktor Eksternal yang dimaksud adalah faktor yang timbul dari lingkungan, masyarakat dan keluarga.

\section{Daftra Pustaka}

Abdul, Yahya Fattah Az-Zawawi, Metode Praktis Cepat Hafal AlQur'an, Solo:Pustaka Iltizam.

Abdul,Yahya Fattah Az-Zawawi, 2013, Metode Praktis Cepat Hafal AlQur'an, Solo:Pustaka Iltizam

Alawiyah,Wiwi Wahid. 2012, Cara Cepat Bisa Menghafal Al-Qur'an, (Jogjakarta: DIVA Press

Departemen Agama RI, 2010, Mushaf Daliyah Al-Qur'an Terjemah da n Tafsir untuk Wanita, Bandung: Jabal,.

Khalil, Manna al-Qattan. Studi ilmu-ilmu Al-Qur'an. Bogor: Litera Antar Nasa Halim Jaya, 2014.

Majdi, Al-Hafizh. 9 Langkah Mudah Menghafal Al-Qur'an. Solo : Aqwam, Ubaid 2014.

Qosim, Amjad. Meski Sibuk pun Bisa Hafal Al-Qur'an. Solo : Al-Kamil Solo, 2013.

Saied, Al-Hafizh. 2016, Karantina Hafal Al-Qur'an Sebulan. Solo : Alam AlMakhtum Pena

Zawawie, Mukhlisoh. 2011, P-M3 AlQur'an Pedoman Membaca, Mendengar, dan Menghafal AlQur'an, Solo:Tinta Medina 